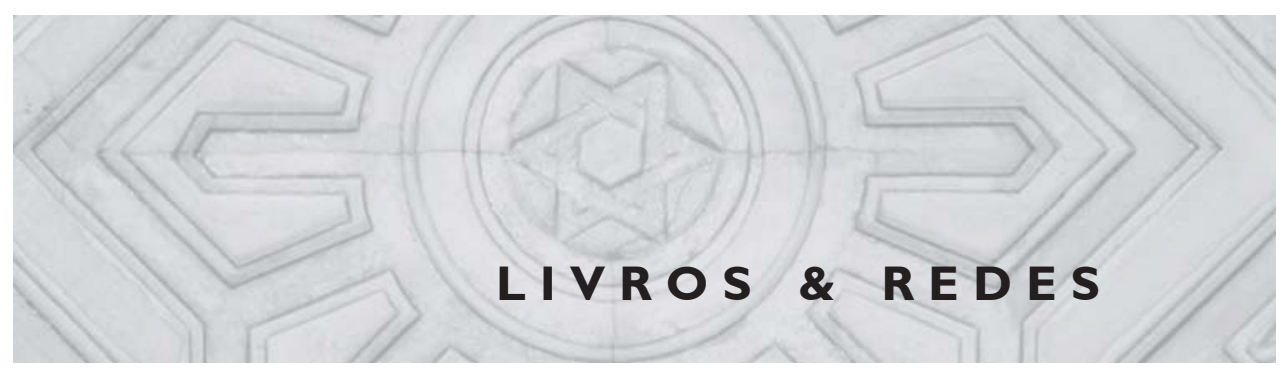

\title{
Limites e fronteiras da eugenia no Oeste dos Estados Unidos
}

\author{
Limits and frontiers of eugenics in the \\ West of the United States
}

\author{
Vanderlei Sebastião de Souza \\ Rua Cardeal Leme, 125/402 \\ 20240-010 Rio de Janeiro - RJ Brasil \\ vanderleidesouza@yahoo.com.br
}

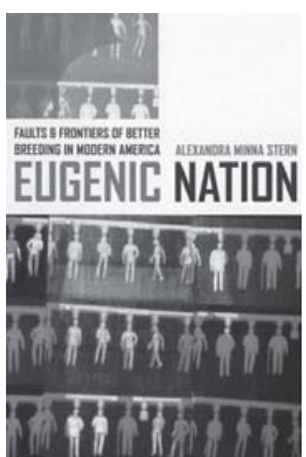

Stern, Alexandra Minna. Eugenic nation: faults and frontier of better breeding in modern America. California: University of California Press, 2005. 347p.

\begin{abstract}
A o contrário da crença bastante difundida, as idéias e as práticas eugênicas não desapareceram do cenário internacional quando da queda do regime nazista na Alemanha. Com uma leitura extremamente original sobre a história da eugenia nos Estados Unidos, a historiadora Alexandra Minna Stern demonstra que é preciso repensar as diferentes permanências, rupturas e permutações do discurso eugênico ao longo do século XX. Em Eugenic nation: faults and frontier of better breeding in modern América, a autora apresenta uma nova interpretação para a história da eugenia norte-americana. Para ela, a refutação das teorias eugênicas teria ocorrido somente nos anos 60 e 70, no auge das lutas pelos direitos civis.

Analisando o movimento eugênico na Califórnia, entre 1910 e 1970, Eugenic nation ajuda a apreender, por um lado, a importância das idéias eugênicas na construção da própria história do Oeste dos Estados Unidos e, por outro, as questões que envolvem a extensão e os limites da ciência médica, da biologia e da genética na formação da sociedade moderna. Ao descrever a eugenia como um multifacetado programa de melhoramento da reprodução humana, a autora demonstra como as teorias sobre hereditariedade foram amplamente empregadas no século XX para explicar as condutas e comportamentos sociais, sobretudo as diferenças de raça, gênero e sexo.

Com o propósito de rever a história da eugenia nos Estados Unidos, o livro questiona as narrativas e cronologias pelas quais esse tema foi, muitas vezes, analisado. Segundo Stern, vários são os motivos para desafiar a predominância do entendimento temporal, local e temático relacionados à história da eugenia. Primeiro, é importante destacar as relações e as não-relações da eugenia com o projeto nazista para a 'higiene da raça', tendo em vista ter sido esse processo obscurecido por sua associação direta com a Segunda Guerra Mundial, o que teria simplificado o contexto no qual as práticas eugênicas ganharam forma. Tal conexão, conforme Stern, além de não dar conta das contingências históricas do período, pode simplesmente beirar o sensacionalismo.
\end{abstract}


Em segundo lugar, a historiografia da eugenia norte-americana, assim como a própria história da medicina, tem sido inteiramente centrada nos principais estados da Costa Leste, sendo parcos os estudos nas variações regionais. Em geral, as atenções são dirigidas para organizações como a Eugenics Record Office e a American Eugenics Society, assim como para trajetórias de eugenistas como Charles Davenport e Madison Grant. No entanto, para Stern, foi no Oeste, e não no Leste, onde a legislação eugênica foi mais elaborada. Diante da imaginária ameaça que imigrantes latinos e asiáticos representavam à civilização branca do Oeste, o discurso eugênico realimentou o imaginário social quanto à possibilidade de preservar a pureza biológica dos antigos colonizadores anglo-saxões. Assim, as idéias eugênicas sobre seleção racial e reprodutiva foram essenciais para reorganizar o Oeste americano, legitimando uma diversidade de práticas em nome da ordem biopolítica.

Em terceiro lugar, a autora explica que, ao colocar os estudos de gênero e sexualidade no centro das análises, a história da eugenia norte-americana é reconfigurada, possibilitando uma substancial revisão temática e temporal. Tal perspectiva ajuda a compreender por que a história da eugenia é muito mais complexa do que aquela até então conhecida. Como já destacamos, Stern entende que a derrota da eugenia não ocorreu nos anos 40, mas sim durante a luta pelos direitos civis, quando os pilares que sustentavam os argumentos eugênicos foram sistematicamente desmantelados. A partir dos anos 60 e 70 o movimento Black Power, o feminismo e o movimento gay uniram-se numa ampla campanha de repulsa às práticas e concepções eugênicas ainda vigentes nos Estados Unidos.

Dado que a eugenia norte-americana é freqüentemente alinhada ao racismo científico, a queda do nazismo e o abandono das várias categorias raciais, em meados dos anos 40 , alimentaram a visão de que a eugenia havia definitivamente desaparecido do discurso médico. Contudo, a autora de Eugenic nation demonstra que, exibindo maior flexibilidade que seus antecessores, os eugenistas do pós-guerra continuaram a aplicar seus conhecimentos com sistemática freqüência nas décadas posteriores. Em lugar da associação entre raça e hierarquias raciais, o repertório eugênico incorporou estudos sobre demografia, sexualidade, biotipologia, psicanálise e antropologia, ajustando-se ao novo cenário científico e social. Guiados por experimentos em endocrinologia e genética humana, os eugenistas passaram a examinar atentamente as funções hormonais dos indivíduos, a vida sexual e matrimonial dos casais, as doenças e suas suscetibilidades genéticas. No entanto, apesar da guinada teórica, Stern explica que o debate sobre eugenia e hereditariedade continuou, até pelo menos o final dos anos 70 , sendo reproduzido no discurso médico e social.

Dividida em seis capítulos, Eugenic nation segue uma narrativa cronológica e temática para explorar as várias faces e temporalidades do pensamento eugênico e hereditarista do Oeste americano. No primeiro capítulo, o enfoque é direcionado para as idéias eugênicas que emergiram no início do século $X X$, especialmente em suas relações com a medicina colonial. A partir da análise da Panamá-Pacific Internacional Exposition - montada em 1915 pela Race Betterment Foundation como parte das comemorações de inauguração do Canal do Panamá -, a 
autora analisa as conexões entre a medicina tropical, a eugenia e os conceitos sobre melhoramento racial. Profundamente vinculada ao darwinismo e à antropologia vitoriana, a medicina tropical norteamericana contribuiu para legitimar idéias eugênicas sobre as diferenças raciais e genéticas. Segundo Stern, a eugenia e a medicina tropical foram criadas com base em ideologias raciais e científicas similares, informadas por noções de raça, germe e genes e pelas concepções de higiene, purificação, segregação e civilização. Nesse sentido, a íntima associação dessas ciências contribuiu sobremaneira para reinventar as narrativas sobre o triunfo da expansão americana no Oeste e no Pacífico.

No segundo capítulo, Stern destaca o olhar dos eugenistas sobre a 'perigosa fronteira' do Oeste americano com o México. A partir de meados dos anos 10, esse limite territorial passou a sofrer um duplo movimento de medicalização e militarização. Uma 'barreira eugênica' foi criada com o objetivo de preservar a nação norte-americana contra os 'bárbaros', 'mestiços' e 'disgênicos' mexicanos. As quarentenas montadas para combater epidemias, higienizar ambientes e defender o Oeste contra doenças e genes do país vizinho contribuíram para fixar preconceitos sobre a suposta inferioridade biológica dos imigrantes latinos. A despeito da proximidade e da similaridade topográfica e climática, o lado mexicano da fronteira foi rapidamente estigmatizado como uma distante entidade geográfica, um território incivilizado, pobre e ameaçador. Stern argumenta que as quarentenas sanitárias colaboraram, ainda, para alargar a cultura da segregação e da violência racial que tomou forma em alguns estados do Oeste, especialmente na Califórnia.

O estudo do processo de institucionalização da eugenia nas primeiras décadas do século XX é outro aspecto bastante relevante nessa obra de Stern. Mantendo-se na vanguarda do pensamento eugênico nacional, o estado da Califórnia criou, especialmente a partir dos anos 20, uma rede de eugenistas, associações e instituições científicas que dominou a agenda das ciências biomédicas e das políticas de saúde pública. Utilizando-se do respaldo social e da moderna ciência da hereditariedade, os eugenistas conseguiram aprovar um grande número de leis e códigos constitucionais, como a esterilização compulsória, o birth control, a proibição dos matrimônios inter-raciais e o controle rigoroso da imigração. Paul Popenoe, Harry Laughlin e Frederick Osborn, entre outros, acreditavam que a legislação eugênica livraria o Estado do gasto de milhões de dólares com doentes que superlotavam as instituições públicas e protegeria o país contra a reprodução da massa de "indesejáveis" que "poluíam" o "sangue e a moral da nação branca e civilizada".

Além desse amplo conjunto de medidas, as instituições eugênicas produziram inúmeras pesquisas com crianças e adolescentes 'delinqüentes', imigrantes, negros, mestiços, homossexuais, 'doentes mentais' e prisioneiros, com o objetivo de medir suas capacidades intelectuais e tendências hereditárias. Testes de QI, estudos psicométricos e exames de identificação criminal foram deliberadamente utilizados, com o intuito de oferecer razões científicas que justificassem, por exemplo, um sistema de ensino público segregado. 
Os argumentos eugênicos também foram freqüentemente utilizados para reforçar as grandes narrativas históricas quanto à excepcionalidade do Oeste na história americana. Stern argumenta, sobretudo no quarto capítulo, que os eugenistas invocaram o evolucionismo de Frederick Jackson Turner para dar consistência e celebrar o mito de criação da progressiva civilização do Oeste. As narrativas sobre a paisagem natural, a exuberância biológica e a riqueza do solo do Oeste foram reapropriadas pelos eugenistas como metáforas para expressar a superioridade dos pioneiros colonos brancos.

Conectados a esses mitos fundadores, os eugenistas apregoaram, especialmente após a Grande Depressão, que o controle populacional e a proteção da família constituíam os meios mais eficientes para evitar a desagregação da sociedade americana. No capítulo cinco, a autora enfatiza que os eugenistas passaram a defender, a partir dos anos 40 , o controle demográfico como veículo da modernidade, democracia liberal e paz mundial. Naquele período o discurso eugênico migrou, portanto, das discussões sobre raça para os conceitos de formação de populações, aproximando-se mais das concepções de Malthus do que das de Mendel.

Entre 1940 e 1960 várias clínicas eugênicas foram criadas na Califórnia com vistas ao aconselhamento médico-matrimonial e reprodutivo, sobretudo às famílias de classe média. A intenção não era somente a de controle populacional, mas também a de regulação da sexualidade, da maternidade, do corpo e do papel da mulher na família moderna. Essas clínicas ofereciam também um amplo conjunto de ferramentas psicométricas e biotipológicas, capazes de 'medir' traços mentais, emocionais e psíquicos de homossexuais e de mulheres cuja conduta sexual era tida como imprópria para o matrimônio.

Nesse sentido, Eugenic nation possibilita compreender como, no contexto da Guerra Fria, a eugenia ajudou a internalizar novas ideologias e conceitos de família, sexualidade, gênero e reprodução, gerando impactos na vida social e nas relações de intimidade. A rígida distinção entre os papéis masculino e feminino estava fortemente baseada em concepções hereditaristas e naturalizadas, cujas características eram fundamentais para a normalidade e a sobrevivência da família, da nação e da civilização ocidental. Ao agir assim, explica Stern, os eugenistas acabaram por reforçar a versão conservadora do 'sexo normal' como função biológica e a do matrimônio como meio natural para a reprodução e a proteção da espécie.

No último capítulo, a autora analisa a organização e atuação dos movimentos sociais e das instituições públicas que passaram a contestar fortemente as medidas eugênicas, nos anos 60 e 70 . O argumento central do amplo movimento consistia em demonstrar que as atitudes em defesa da 'boa reprodução', da preservação dos valores arianistas, da distinção de sexo e gênero, da opressão sobre negros, mulheres, gays e lésbicas estavam diretamente associadas a um programa autoritário e de cunho fascista, incompatíveis com as instituições democráticas e liberais americanas. A luta dos ativistas dos direitos civis passou assim, obrigatoriamente, pelo combate ao legado e à permanência das teorias e práticas eugênicas. 
Em Eugenic nation, Alexandra Minna Stern não trata somente da história da eugenia e das concepções hereditaristas nos Estados Unidos, mas principalmente da intrínseca relação entre ciência, sociedade e política. A autora demonstra que os limites e as fronteiras da reprodução eugênica no Oeste americano estiveram intimamente associados a um grande projeto político de construção de um modelo ideal de civilização que buscou legitimidade nos mitos, na memória nacional, no racismo e nos valores culturais conservadores daquela sociedade.

Porém, considerando a rápida expansão dos estudos sobre biologia molecular e genética nas últimas três décadas, Eugenic nation deve ser lida como uma obra que possibilita pensar questões paradoxais que envolvem a sociedade contemporânea. Os recentes projetos científicos relacionados à reprodução humana e ao minucioso mapeamento genético abrem um amplo campo de debate quanto aos limites éticos que orientam a moderna ciência biomédica. Como destaca Stern, é necessário estarmos vigilantes para os caminhos que as novas tecnologias genéticas vêm trilhando, especialmente no que diz respeito aos métodos reprodutivos, às discussões sobre doenças hereditárias e à existência de anormalidades cromossômicas. Não se trata de impedir o desenvolvimento da ciência, como bem conclui a autora, mas de desafiar os entendimentos estabelecidos sobre o modelo de sociedade que se quer construir e sobre quem e o que é considerado normal ou anormal. Finalmente, Stern sugere que o problema atual não está em definir como eugênicas ou não as novas tecnologias e as práticas genéticas e reprodutivas; trata-se de definir o que se espera desses novos conhecimentos médicos, assim como de definir se todos, ou uma pequena minoria, poderão usufruir dessas conquistas. 


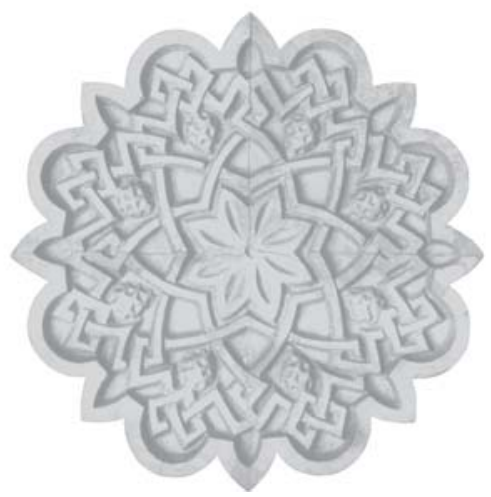

